\title{
Effects of Neoadjuvant Fluorouracyl-Adriamycin- Cytoxan (FAC) Chemotherapy Response to CD4 + Serum Levels In Breast Cancer
}

\author{
Ade Permana $^{1}$, Benny Kusuma ${ }^{1 \#}$, Nur Qodir ${ }^{1}$, Erial Bahar $^{2}$ \\ ${ }^{1}$ Department of Surgery, Faculty of Medicine, Universitas Sriwijaya \\ ${ }^{2}$ Department of Anatomy, Faculty of Medicine, Universitas Sriwijaya \\ \# Correspondence Author Email : bennyk_onk@yahoo.com
}

\begin{abstract}
Introduction. CD4+ T-helper has an important role in immune system modulation especially to maintain long-term anti tumor effect. CD4+ also serves to activate CD8+ for destroyed the tumor cells. It was expected there were role of immunity on tumor growth and response of breast cancer chemotherapy to CD4+ levels serum. Furthermore, this study was aimed to investigate the effects of neoadjuvant chemotherapy on CD4+ levels in patients with locally advanced breast cancer at General Hospital Dr. Mohammad Hoesin Palembang.

Method. This study was a non-comparable clinical trial by looking at serum CD4+ levels in patients with locally advanced breast cancer before and after neoadjuvant chemotherapy.

Results. Of the 30 subjects the subject age ranged from 33-66 years with an average of 45 years. There were 17 patients with contraception history (56.7\%), 13 patients with family history of breast cancer (43.3\%). From this study, it was obtained 23 patients with good chemotherapy response $(76.7 \%)$ and there were 7 patients who had poor chemotherapy response after neoadjuvan chemotherapy (23.3\%). Paired t-test analysis showed that there was a significant difference in mean CD4+ count before and after neoadjuvan chemotherapy. At the CD4+ level before chemotherapy 775.55 had a sensitivity of $60 \%$ and a specificity of $57 \%$ (cut of point). While CD4+ levels after chemotherapy 470.85 with sensitivity of $60 \%$ and specificity of $57 \%$.
\end{abstract}

Conclusion. CD4+ pre-chemotherapy examination had a sensitivity score of $60 \%$ and a specificity of $57 \%$ in predicting neoadjuvant chemotherapy response.

Keywords: CD4+, chemotherapy, breast cancer, neoadjuvant fluorouracyl-adriamycincytoxan 


\section{SSS SRIWIJAYAJOURNABOFSURGERY}

\section{Introduction}

Breast cancer is the most common malignancy in women with a WHO case number in 2012 of 1.67 million cases (25\% of all malignancies). There are 883,000 cases in developing countries and 794,000 in developed countries. The number of breast cancer cases in Southeast Asia is 240,000 cases with a mortality rate of 110,000 cases. ${ }^{1}$ Breast cancer is one of the most cancer types in Indonesia. Based on Pathological Based Registration in Indonesia, breast cancer is the number one with a relative frequency of 18.6\%. (Cancer Data in Indonesia Year 2010, according to Histopathological data, Cancer Registry Agency of Indonesian Pathology Specialist Association (IPSA) and Indonesian Cancer Foundation (ICF). It is estimated that the incidence rate in Indonesia is $12 / 100,000$ women, whereas in the United States are about $92 / 100,000$ women with a high mortality of $27 / 100,000$ or $18 \%$ of deaths found in women. In Indonesia, more than $80 \%$ of cases are found in advanced stage, so the treatment effort becomes difficult. $^{2}$

At General Hospital Dr. Mohammad Hoesin (MHH) Palembang, the number of cases of breast cancer in 2013 is 832 cases and most of them is stage III or LABC, stage III A 26.53\% and stage IIIB $48.98 \% .{ }^{4}$ Neoadjuvant chemotherapy is a treatment option for locally advanced breast cancer patients. The clinical response criteria used after neoadjuvant chemotherapy are RECIST (Response Evaluation Criteria In Solid Tumors), which are complete, partial, stable and progressive. ${ }^{6} \mathrm{CD} 4+$ serves as the basis of the immune/immune priming system of Cytotoxic T Lymphosite (CTL) cells. CD4+ T helper has an important role in immune system modulation especially maintaining a long-term antitumor effect. ${ }^{9}$ AJ Madu et al in his study reported that there was a significant decrease between CD4 values before and after chemotherapy. ${ }^{10}$ Gabioglu et al also reported that patients with LABC who received Antracyclin-based neoadjuvant chemotherapy induced an increase in T-cells. ${ }^{11}$

Given the role of immunity to tumor growth and the chemotherapy response in breast cancer, especially with CD4+ serum levels, we would like to investigate the effects of neoadjuvant chemotherapy on CD4+ levels in patients with locally advanced breast cancer at Dr. Mohammad Hoesin Palembang. 


\section{SSS SRIWIJAYAJOURNAB OFSURGERY}

\section{Methods}

It was a non-comparable clinical trial by looking at CD4+ serum levels in patients with locally advanced breast cancer before and after neoadjuvant FAC chemotherapy at Dr. Mohammad Hoesin Hospital Palembang. The sample of this study at least 30 locally advanced breast cancer patients who met the inclusion and exclusion criteria for the $\mathrm{T}$ test requirements. Sampling was done by consecutive sampling, all subjects that come and meet the criteria of sample selection were included in the study until the required number of subjects is accomplished. All patients were given informed consent prior to participate in the study. CD4+ blood samples was taken and examined with flow cytometry BD FACSCanto.

Characteristics of breast cancer patients were divided over age, family planning history, family history, and clinicopathology symptoms were described descriptively and data are presented in table form and analyzed using paired $\mathrm{T}$ test to determine effectiveness with SPSS version 21 program.

\section{Results}

Based on age, the mean age of advanced breast cancer patients is $45,97 \pm 10,526$ years old with age range $30-66$ years, age $\geq 40$ years is 19 people $(63,3 \%)$ and age $<40$ years is 11 (36.7\%). The majority of patients with locally advanced stage breast cancer already have a children $(96.7 \%)$ and only $1(3.3 \%)$ have no children. Locally advanced breast cancer patients with birth control history is $17(56.7 \%)$ and $13(43.3 \%)$ had no birth control history. A total of 13 people $(43.3 \%)$ of patients with advanced breast cancer have a history of the same disease in the family.

\section{Table 1. Baseline Characteristic}

\begin{tabular}{llcc}
\hline Characteristic & & $\mathrm{n}$ & $\%$ \\
\hline Age & $\geq 40$ years & 19 & 63,3 \\
\hline $\begin{array}{l}\text { Birth control } \\
\text { history }\end{array}$ & Yes years & 11 & 36,7 \\
\hline & & 17 & 56,7 \\
\hline Marital status & Mo & 13 & 43,3 \\
\hline & Married & 19 & 63,3 \\
\hline Family History & Yes & 11 & 36,7 \\
\hline & No & 13 & 43,3 \\
\hline & & 17 & 56.7 \\
\hline
\end{tabular}




\section{SSS SRIWIJAYAJOURNAB OPSURGERY}

In this study there were estrogen receptor (ER) positive of 20 people $(66,7 \%)$, progesteron receptor (PR) positive of 25 people $(83,3 \%)$ and Her2/Neu positive of 9 people. Her2/Neu +++ of 4 people (13,3\%), Her2/++ of 3 people and Her $2+$ of 2 people $(6.7 \%)$. Ki67 levels of both $\geq 20 \%$ and $<20 \%$ obtained as much, ie 15 people. Of the 30 patients of advanced stage breast cancer patients received a good chemotherapy response of 23 people $(76.7 \%)$ and patients with poor response of 7 people $(23.3 \%)$.

Table 2. Histopathology Characteristics

\begin{tabular}{llcc}
\hline Characteristic & & $\mathrm{N}$ & $\%$ \\
\hline ER & Positive & 20 & 66.7 \\
\hline PR & Negative & 10 & 33,3 \\
\hline Positive & 25 & 83,3 \\
\hline NER2 & Negative & 5 & 16,7 \\
\hline & $\begin{array}{l}\text { Positive } \\
1(+)\end{array}$ & 4 & 13,3 \\
\hline & Positive & 3 & 10,0 \\
\hline $2(++)$ & & 6,7 \\
\hline Ki67 & Positive & 2 & 70,0 \\
\hline & $3(+++)$ & 21 & 50,0 \\
\hline Chemotherapy response & Pegative & 15 & 50,0 \\
\hline & Poor $20 \%$ & 15 & 23,3 \\
\hline & Good & 7 & 76,7 \\
\hline
\end{tabular}

From the statistical analysis, it was found that there was a difference of CD4+ serum levels before and after chemotherapy $(\mathrm{p}=0,000)$ in which CD4+ serum levels after chemotherapy decreased significantly compared to before chemotherapy. The value of CD4+ before chemotherapy of 775.55 had a sensitivity of $60 \%$ and a specificity of $57 \%$ (cut of point). While CD4+ levels after chemotherapy of 470.85 with sensitivity of $60 \%$ and specificity of $57 \%$. 


\section{SISS SRIWIJAYA JOURNABOFSURGERY}

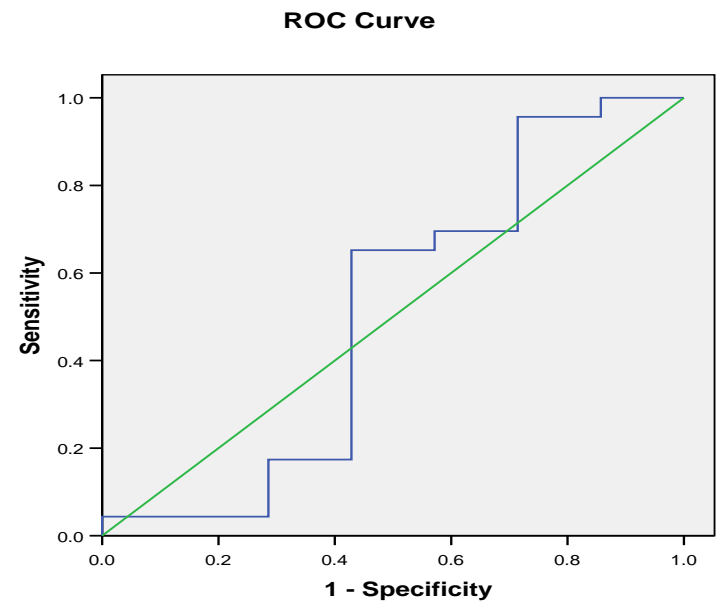

Figure.1 Curve of intersection sensitivity and specificity on CD4+ value prior to chemotherapy of locally advanced breast cancer patients

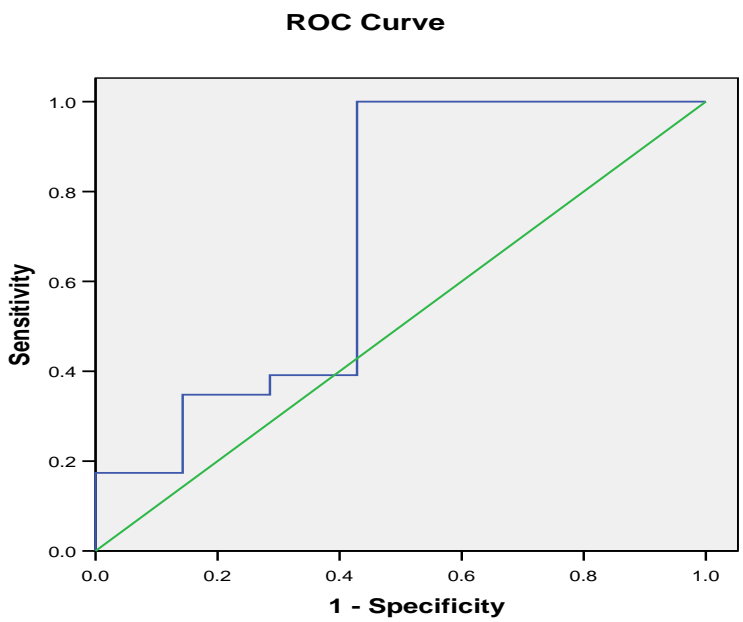

Figure.2 Curve of intersection sensitivity and specificity on CD4+ value after chemotherapy of locally advanced breast cancer patients

\section{Discussion}

Breast cancer is the most common malignancy in women with the number of cases by WHO in 2012 of 1.67 million cases (25\% of malignancy). There are 883,000 cases in developing countries and 794,000 in developed countries. The number of breast cancer cases in Southeast Asia is 240,000 cases with a mortality rate of 110,000 cases $^{1}$. The incidence of breast cancer increases with age, every 10 years, the risk of cancer increases twice among menopause women. The average incidence of breast cancer is among women aged 45 years 


\section{SSS SRIWIJAYAJOURNABOFSURGERY}

and over. ${ }^{13}$ In this study of 30 subjects, we obtained age ranged from 30-66 years with a mean of $44.97 \pm 10,206$ years. There are 17 patients with birth control history (56,7\%), 13 patients with family history of Breast Cancer (43,3\%).

Immunohistochemical characteristics of breast cancer patients in this study are included ER positive of $66.7 \%$, PR positive of $83.3 \%$ and $\mathrm{Her} 2 / \mathrm{Neu}+1,+2$ and +3 of $13.3 \%, 10 \%$ and $6.7 \%$, respectively. Ki67 levels $\geq 20 \%$ in breast cancer patients in this study were similar to KI67 $<20 \%$. Immunohistochemistry is used not only for prognosis but also determines the therapy given to breast cancer patients. ${ }^{15}$ There are 23 patients with a good chemotherapy response $(76.7 \%)$ and 7 patients with poor chemotherapy response after neoadjuvant chemotherapy $(23.3 \%)$.

CD4+ has an important role in immune system modulation especially in long-term antitumor effects. ${ }^{10}$ In this study, CD4+ before neoadjuvant chemotherapy, there are $6(20 \%)$ patients with low CD4+ and $18(60 \%)$ patients with normal CD4+ and there are $6(20 \%)$ patients with high CD4+ count. After neoadjuvant chemotherapy there were 15 (50\%) patients with low CD4+ count and $13(43.3 \%)$ patients with normal CD4+ count and 2 (6.7\%) patients with high CD4+. Overall, there was a decrease in CD4+ levels after chemotherapy, which could decrease the function of CD4+ T as a helper or cell effector for anti-tumor response. ${ }^{15}$ Statistical test results using paired t-test showed that there was a significant difference in mean CD4+ count before chemotherapy neoadjuvant against the chemotherapy response. Similarly with CD4+ after neoadjuvant chemotherapy there was a significant difference in mean CD4+ count after neoadjuvant chemotherapy on chemotherapy response. This is consistent with the study conducted by AJ Madu et al, in his study there were significant differences in CD4 T levels before and after chemotherapy, especially in the cyclophosphamide and adriamycin regimens, and combinations of cyclofofamide, vincristine, pro-carbazine and prodnisolone (COPP). ${ }^{10}$ To assess whether the CD4+ is an accurate tool in predicting chemotherapy response, a diagnostic test with gold standard on chemotherapy response is required. At the CD4+ level before chemotherapy of 775.55 had a sensitivity of $60 \%$ and a specificity of $57 \%$ (cut of point). While CD4+ levels after chemotherapy of 470.85 with sensitivity of $60 \%$ and specificity of $57 \%$.

\section{Conclusion}

CD4+ pre-chemotherapy examination had a sensitivity score of $60 \%$ and a specificity of $57 \%$ in predicting neoadjuvant chemotherapy respons 


\section{SIS SRIWIJAYAJOURNAB OPSURGERY}

\section{References}

1. World Health Organization. Breast Cancer Estimated Incidence, Mortality and Prevalence Worldwide in 2012.

2. Breast Cancer Management Guidelines. National Cancer Committee. Ministry of Health of the Republic of Indonesia. 2015

3. Mohammad Hoesin Hospital Palembang. Medical Records of RSMH 2013.

4. Ade, Y. Characteristic of Young Breast Cancer Patients in Dr. Mohammad Hoesin Palembang. 2014

5. Sukardja IDG. Clinical Oncology. $2^{\text {nd }}$ ed. Surabaya: Airlangga University Press, 2000. 90150.

6. Purwanto H, Handojo D, Haryono SJ, Harahap WA, editor. Inside Therapy: Breast Cancer Management Guideline. Jakarta: Indonesian Oncology Surgeon Association; 2015. page. 70-74, 83-84

7. Selgrade M K, Hu P C, Miller F J, Graham J A . Effects of immunosuppression with cyclophosphamide on acute murine cytomegalovirus infection and virus-augmented natural killer cell activity. American Society of Microbiology December 2000;38:1046-55

8. Boedina S. Elements that play a role in immunological reactions. In: Immunology diagnosis and laboratory procedures. Jakarta: FK UI; 2001.14-95.

9. Rene EM, Ferry O, Rienk O, Cornelis J. CD4 T cells and their role in antitumor immune responses. J. of experimental medicine 1999;189:753-6.

10. AJ Madu, dkk. Pattern of CD4 T-lymphocyte Values in Cancer Patients on Cytotoxix Theraphy. Ann Med Health Sci Res.2013 Oct-Des; 3 (4): 498-503.

11. Cabioglu N, Muslumanoglu, Tutuncu Y, Adin-Cinar, Gurel N, at al. Immune Changes in Patients with Locally Advanced Breast Cancer Receiving Neoadjuvant Chemotherapy. Turk J Immunol, 2008; 13: 15-20.

12. Manuaba TW. Breast Cancer in the Solid Cancer Management Guidelines PERABOI 2010. Sagung Seto. Jakarta. 17-48

13. Collection of Scientific Text. Association of Indonesian Oncology Surgeons (PERABOI). National Congress VI: 2003. 


\section{SIS SRIWIJAYAJOURNAB OPSURGERY}

14. American Joint Committee on Cancer. Breast Cancer Staging $7^{\text {th }}$ Edition. 2010. Available at:https://cancerstaging.org/references-tools/quickreferences/Documents/BreastMedium. pdf, diakses 20 Agustus 2017).

15. Weigel, M.T., and Dowsett M. 2010.Review, Current and emerging biomarkers in breast cancer: prognosis and prediction. Endocrine- Related Cancer,17,R245-R262.

16. YersalO., and Barutca S. 2014.Biological Subtypes of Breast Cancer: Prognostic and Therapeutic Implications. World J Clin Oncol,5(3),412-424

17. Daly JM, Bertagnolli M, Decosee JJ, Morton BL. Oncology . In: Schwartz SI editor. Principles of surgery. 7th ed.( Int'l ed). Vol I. Singapore : Mc Graw-Hill; 1999.p.297-360

18. Chu E, De Vita VC. Principles of Medical Oncology. In : De Vita VC, Hellman, Rosenberg SA. Editors. Cancer, principles \& practice of oncology. 7th ed. Philadelphia : Lippincott William \& Wilkins; 2000.p.95-306

19. Tjindarbumi. Early detection of breast cancer and removal. In: Muchlis Ramli, Rainya Umbas, Sonar S, editor. Early detection of cancer. Jakarta: FKUI, 2005.32-53

20. Meric-Bernstorm F, Polloock RE, Oncology. In: Brunicardi FC. Editor Schwatz principles of surgery. 8th ed. Mc Graw Hill;2005.p.249-90

21. Soebandiri. Basic principles of rational and pragmatic internal medical cancer management. Magazine of internal medicine. Udayana, special edition of PKB IX vol 2; no 3; September 2001.p.385-95

22. Gianni Beretta. Cancer treatment Medical Guideline. 10th ed . Milan: Farmitalia Carlo Erba; 1991

23. Contran RS, Kumar V, Robbins SL. Robin Pathologic basis of Disease. 5th ed. Philadelpia : WB Saunders, 1994

24. Stites DP, Terr Abba I, Parslow TP, Medical Immunology, 9th ed, Stamford Connecticut, USA: Appleton \& Lange, 1997

25. Abbas A, Lichtman AH, Pober JS. Cellular and Molecular Immunology. 5th ed. Philadelphia: Elsevier-Saunders; 2005. p. 4-15,22-3,65-80,81-103,182-7,247-53,2589,266,268-9,279-80,290-5.

26. Roitt IM, 1998. Essentiale Immunology, 6th ed. Blackwell sci. publ. London.

27. Goodman JW. The Immune Response, in Basic and Clinical Immunologi. 8th ed. Stites DP, Terr A I eds.,Prentice-Hall Int.Inc.,USA. 


\section{SIS SRIWIJAYAJOURNAB OFSURGERY}

28. Kresno SB. The immunological aspect of cancer. Nelwan et al eds. Symposium 4th Jakarta Antimicrobial Update 2003. Sub Division of Tropical Disease and Infection Department of Internal Medicine Faculty of Medicine Universitas Indonesia National General Hospital Dr. Cipto Mangunkusumo. Jakarta. 2003: 59 - 77.

29. Constatinides P. General Pathobiologi. Connecticut: Appleton \& Lange,1994 : 173 - 90.

30. Giles JT, Palat CT, Chien Susan H, Chang ZG, Kennedy DT. Evaluation of Echinacea for Treatment of the Common Cold. Pharmacotherapy, 2000; 20(6):690-7

31. Soini Y. Paakko P, Lehto V. Histopathological evaluation of apoptosis in cancer. Am J Pathol 1998, 153:1041-53. Available from : URL: http://www.ajp.amjpathol.org/cgi/content/full/153/4/1041. Diakses tanggal 24 Januari 2009

32. Jong M, Masaki T, Yoshio S, Jeeva M, Guido F, John C. Early role of CD4 th1 cells and antibodies in HER2 adenovirus vaccine protection against autochthonous mammary carcinomas. The Journal of immunology 2005 ; 174: 4228-36. 